Perinatology pISSN 2508-4887 • elSSN 2508-4895

\section{Original article}

Perinatology Vol. 30, No. 3, September, 2019

https://doi.org/10.14734/PN.2019.30.3.154

\title{
Analysis of Major Factors Affecting False Positive Results in Neonatal Screening Test within 3 Days after Birth
}

Tae Kyu Kim, MD,

Seung Hyun Lee, MD,

Seung Taek Yu, MD,

Yeon Kyun Oh, MD

Department of Pediatrics, Wonkwang University School of Medicine, Iksan, Korea
Received: 25 May 2018

Revised: 24 November 2018

Accepted: 9 June 2019

Correspondence to

Seung Hyun Lee, MD

Department of Pediatrics, Wonkwang

University School of Medicine, 460

Iksan-daero, Iksan 54538, Korea

Tel: +82-63-859-1510

Fax: $+82-63-853-3670$

E-mail: courteouslee@gamil.com

Copyright@ 2019 by The Korean Society of Perinatology

This is an Open Access article distributed under the terms of the Creative Commons Attribution Non-Commercial License (http://creativecommons.org/ license/by-nc/4.0/), which permits unrestricted non-commercial use, distribution, and reproduction in any medium, provided that the original work is properly cited.
Objective: We examined the factors affecting the false positive results in the accidental neonatal screening test (NST) within 3 days after birth and tried to find out the most relevant factors.

Methods: From January 2011 to December 2016, we reviewed the electronic medical records of 142 patients with a gestational age of 34 weeks or more who had false positives at the first NST. NST was performed by tandem mass spectrometry. We collected information on gestational age, birth weight, delivery method, Apgar score at the time of birth. Postnatal exam time, body weight, feeding volume and parenteral nutrition, antibiotics, and steroid administration were also investigated at the time of NST.

Results: In the first NST, there were 102 cases of congenital adrenal hyperplasia, 27 cases of congenital hypothyroidism, nine cases of galactosemia and one case of homocystinuria. Gender, birth weight, and delivery method were statistically significant $(P<0.05)$ at the time of birth using Pearson Chisquare method. There were significant differences in body weight, feeding volume, parenteral nutrition at the time of NST $(P<0.05)$. In binary logistic regression analysis, the gender and the body weight seemed significant statistically.

Conclusion: Male sex and weight were identified as major factors of the false positive results in the NST performed within 3 days after birth, but further studies seemed to be needed. In the case of patients with short admission period or insufficient perinatal information, the first NST after birth should be performed at the time of outpatient department or after precise information collection.

Key Words: Neonatal screening, Tandem mass spectrometry, False positive reactions

서론

신생아 시기에 선천성 대사이상질환의 선별검사(neonatal screening test, NST)는 정상 적인 성장과 발달을 위한 조기 진단의 중요성과 이에 따른 치료의 효율성 때문에 많은 나라 에서 시행되고 있다. 우리나라의 경우 1985년 처음으로 도입되었고, ${ }^{1}$ 기존의 페닐케톤뇨증, 선천성 갑상선기능저하증과 함께 2006년부터 단풍당뇨증, 호모시스틴뇨증, 갈락토스혈증 및 선천성 부신과형성증 등의 4 개 질환을 추가하여 모두 6개 질환을 대상으로 시행하고 있 다. 이들 질환에 대한 선별검사로는 Guthrie법으로 알려진 세균학적억제법(bacterial inhibition assay)을 시초로 효소비색법(enzymatic colormetric method), 효소면역법(enzyme immunoassay), 방사면역법(radioimmunoassay) 등이 개발되어 왔지만, 1990년대 초부터 도입된 이중질량 분광분석법(tandem mass spectrometry, 탠덤매스)이 최근에 가장 많이 사용되고 있다. ${ }^{2}$

새로운 대사질환에 대한 검사가 추가된다면 위양성 결과가 증가할 수 있고, ${ }^{3} 20$ 가지 이상 의 질환에 대하여 탠덤매스 검사로 신생아 선별검사를 하는 경우 위양성 결과가 약 $0.33 \%$ 정도 발생하며 전체적으로는 약 2,400 명의 환아당 1 예 정도로 나올 수 있다. ${ }^{4}$ 갑상선기능저 하증의 경우 진단기준을 조정하여 재검 비율에 변화를 준 연구도 있었고 ${ }^{5}$ 미숙아, 심한 스트 레스를 받은 환자, 저체중 출생아, 분만 전후 임산부나 신생아의 요오드 노출, 모체의 갑상선 
항체 여부 등이 위양성을 보일 수 있어 선별검사로서 갑상선자 극호르몬과 T4 검사의 병행을 추천하기도 하였다. ${ }^{6}$ 갑상선기능 저하증뿐만 아니라 탠덤매스 결과에 영향을 줄 수 있는 요인으 로 너무 이른 검체 채취, 미숙아 및 저체중 출생아, 경정맥영양, 항생제 및 스테로이드 투여 등 신생아들의 치료-환경적 요인들 이 언급되었다.?

일반적으로 대사이상질환의 조기 발견 및 중재를 위한 탠덤 매스 검사는 출생 후 3-7일경에 이루어진다. 본 연구에서는 여 러 가지 상황으로 출생 후 3 일 이내에 초회 탠덤매스 검사에서 양성을 보였으나 재검에서 정상 판독를 받았던 환아들을 대상 으로 위양성 결과에 영향을 미친 인자들을 확인하고 그중 가장 관련성이 높은 항목을 찾고자 하였다. 이를 통하여 검체 채취가 부득이하게 3 일 이내에 진행되어야 하는 경우나 출생 시각을 기 준으로 만 72 시간이 되기 전에 검체 채취를 한 경우에 판독상 고 려해야 할 인자들을 알아보고자 하였다.

\section{대상 및 방법}

본원에서는 신생아 중환자실 및 신생아실에 입원한 환자들의 혈액학적 검사와 함께 초회 NST 검사를 생후 3-7일경에 시행 하고 있다. 2011년 1월부터 2016년 12월까지 출생시 재태 연 령 34주 이상 37주 미만의 후기 조산아(late preterm infant)와 재태 연령 37-40주인 만삭아 중에서 지역 분만기관에서 전원 시 출생 시점의 정보가 잘못되었거나 연고지 문제로 NST를 시 행할 수 없는 지역으로 퇴원하는 경우, 종교나 기타 개인적인 이 유 등으로 출생 후 3 일 이내에 NST를 시행하였던 환자 170 명 을 연구 대상으로 하였다. 본 연구 제안서는 원광대학교병원 기 관윤리위원회(IRB)에서 승인되었다(과제 번호: WKUH 201805-018).

이 중 채혈량 부족 등을 포함하는 초회 검사상 오류로 재검을 한 경우 2 명, 초회 검사에서는 정상이었으나 2 차 검사에서 이상 이 보였던 경우 1 명, 초회 및 추적검사에서 판독이 서로 다른 경 우 1 명을 제외하였다. 초회 NST 검사에서 이상 소견을 보였으 나 재검에서 정상 판독을 받았던 142 명의 환자를 위양성군으 로 연구를 진행하였으며, 출생시 미숙아, 저체중 출생아 및 수 유 진행의 문제로 재검을 하였지만 두 차례 모두 정상 결과를 보 인 경우 23 명을 대조군으로 하여 탠덤매스 검사의 위양성 결과 에 영향을 주는 요인을 파악하고자 하였다. 연구 기간 대상 환자 들의 NST는 서울의과학연구소(Seoul Clinical Laboratories) 단 일기관의 탠덤매스 결과를 기준으로 하였다. 선별검사의 참고 치는 phenylalanine $<2.3 \mathrm{mg} / \mathrm{dL}$, leucine $<4.0 \mathrm{mg} / \mathrm{dL}$, galactose
$<11.0 \mathrm{mg} / \mathrm{dL}$, thyroid stimulating hormone (TSH) $<10.0 \mathrm{uU} / \mathrm{mL}$, 17-hydroxyprogesterone $<6.0 \mathrm{ng} / \mathrm{mL}$, methionine $<1.3 \mathrm{mg} / \mathrm{dL}$ 였다. 탠덤매스 검사는 약 20여 종 이상의 대사이상질환에 대한 결과를 알 수 있지만 본 연구에서는 기본 6 가지 질환들 위주로 비 교하였다.

출생시 인자로 성별, 재태 연령, 출생 체중, 분만 방식, 산모의 갑상선질환 병력에 대한 자료를 조사하였고, 분만시 신생아 상 태를 가늠하기 위한 기준은 신생아 사망률과 관련이 있는 5 분 Apgar 점수를 참고하였다. 탠덤매스 검사 채혈시 교정 연령, 체 중, 수유량 및 비경구적 영양(parenteral nutrition), 항생제 그리 고 스테로이드 투여도 조사하였다. 상대적 위험도를 구하기 위 하여 재태 연령 및 검사시 교정 연령(34-36주, 37주 이상), 출 생 체중 및 검사시 체중( $\geq 2,500$ g vs. $1,500-2,500$ g vs. 1,000$1,500 \mathrm{~g})$, Apgar 점수(7-10 vs. 4-6 vs. 0-3), 체중 $(\mathrm{kg}$ )당 수유량 ( $\geq 120 \mathrm{~mL}$ vs. $100-120 \mathrm{~mL}$ vs. $80-100 \mathrm{~mL} v \mathrm{vs} .<80 \mathrm{~mL}$ ) 등을 계층화하였다.

수집된 자료에 대한 통계적 분석은 SPSS for Windows version 21.0 (IBM Corp., Armonk, NY, USA)을 이용하였다. 성 별, 재태 연령, 출생 체중, 분만 방식, Apgar 점수 및 아미노산 (Trophamin injection 6\%, Choongwae, Dangjin, Korea), 지질 (SMOFlipid ${ }^{\circledR} 20 \%$, Fresenius Kabi Korea, Seoul, Korea) 투여 그리고 항생제(Rukasyn ${ }^{\circledR}$, Samjin, Seoul, Korea; Netilmicin ${ }^{\circledR}$, Kuhnil, Seoul, Korea) 투여 여부와 관련된 분석은 Pearson's Chi-square test를 이용하여 비교하였으며, 주요 변수들의 상 대적 위험도를 평가하기 위하여 logistic regression test를 사 용하였고 $P$ 값이 0.05 미만인 경우를 통계적으로 의미가 있다고 판단하였다.

\section{결과}

위양성군과 대조군 사이의 인구학적 특성을 비교하였을 때 통계적으로 유의미하게 위양성군에서 남자의 비율이 많았고, 재태 주수가 많았으며, 출생 체중이 컸고 질식분만의 비율이 컸 다. 산모의 갑상선질환에 대한 분포는 유의미한 차이를 보이지 않았다(Table 1).

142 명의 위양성군 중에서 초회 NST에서 이상 소견을 보인 결 과로 선천성 부신과형성증이 가장 많은 102명(71.8\%)이었고, 이어서 선천성 갑상선기능저하증 27명(19.0\%), 갈락토오스혈 증 9명(6.3\%), glycine 농도 증가 2명(1.4\%), propionylcarnitine 농도 이상 2명(1.4\%), tyrosine 농도 증가 2명(1.4\%), 호모시스 틴뇨증 1 명 $(0.7 \%)$ 이 있었다. 이 중 두 가지 이상 소견을 보인 환 
Table 1. Demographic Characteristics at Birth according to Neonatal Screening Test Results

\begin{tabular}{|c|c|c|c|}
\hline Demographic parameters & False-positive group & Normal group & $P$-value \\
\hline Total & 142 & 23 & \\
\hline Male sex & $93(65.5)$ & $9(39.1)$ & 0.016 \\
\hline Gestational age (weeks) & $36.37 \pm 1.62$ & $35.46 \pm 1.50$ & 0.058 \\
\hline 34 to $<37$ & $91(64.1)$ & $20(87.0)$ & \\
\hline 37 to 40 & $51(35.9)$ & $3(13.0)$ & \\
\hline Birth weight (kg) & $2.65 \pm 0.49$ & $1.95 \pm 0.25$ & 0.000 \\
\hline$\geq 2.5$ & $84(59.2)$ & $1(4.3)$ & \\
\hline 1.5 to $<2.5$ & $56(39.4)$ & $21(91.4)$ & \\
\hline 1.0 to $<1.5$ & $2(1.4)$ & $1(4.3)$ & \\
\hline Vaginal delivery & $68(47.9)$ & $5(21.7)$ & 0.019 \\
\hline Maternal thyroid state & & & 0.125 \\
\hline Normal & $135(95.1)$ & $20(87.0)$ & \\
\hline Hyperthyroidism & $2(1.4)$ & $0(0.0)$ & \\
\hline Hypothyroidism & $5(3.5)$ & $3(13.0)$ & \\
\hline \multicolumn{4}{|l|}{ Apgar score } \\
\hline At 1 minute & $7.42 \pm 1.67$ & $7.56 \pm 1.27$ & 0.552 \\
\hline $7-10$ & $27(19.0)$ & $6(26.1)$ & \\
\hline $4-6$ & $111(78.2)$ & $17(73.9)$ & \\
\hline $0-3$ & $4(2.8)$ & $0(0.0)$ & \\
\hline At 5 minute & $8.63 \pm 1.65$ & $9.09 \pm 0.67$ & 0.506 \\
\hline $7-10$ & $134(94.4)$ & $23(100.0)$ & \\
\hline $4-6$ & $5(3.5)$ & $0(0.0)$ & \\
\hline $0-3$ & $3(2.1)$ & $0(0.0)$ & \\
\hline
\end{tabular}

Values are presented as mean \pm standard deviation or number (\%).

자는 3명이었다(Fig. 1).

일반적으로 출생 후 3-7일에 첫 번째 NST를 시행하게 되는 데 이번 연구 대상에서 출생에서 검사한 시각까지 위양성군의

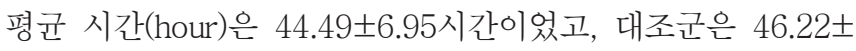
8.27 시간이었으며 $(P=0.762)$, 각 교정 연령 시점에서 측정한 체 중 $(\mathrm{kg})$ 도 $2.61 \pm 0.49 \mathrm{~kg}$ vs. $1.93 \pm 0.25 \mathrm{~kg}(P=0.000)$ 으로 나타났 다. 미숙아의 경우 입원 기간이 길어지며 재태 연령 및 출생 체중 에 따라 수유량에 차이가 있고, 수유량에 따라 환자에게 공급하 는 총경정맥영양 구성에 차이가 발생한다. 첫 번째 NST 시행시 수유량 $(\mathrm{mL} / \mathrm{kg} / \mathrm{day})$ 에서 위양성군은 $105.65 \pm 34.18 \mathrm{~mL} / \mathrm{kg} / \mathrm{day}$, 대조군은 $89.40 \pm 39.69 \mathrm{~mL} / \mathrm{kg} / \mathrm{day}$ 로 차이가 있었다 $(P=0.045)$. 총경정맥영양에서 대표되는 아미노산이 투여된 경우는 위양성 군에서 13명(9.2\%), 대조군에서 8명(34.8\%), 지질은 각각 5명 (3.5\%) vs. 7 명(30.4\%)으로 두 군 간에 차이가 있었다 $(P=0.001$, $P=0.000)$. 항생제 투여 여부에서는 위양성군과 대조군이 각각 49명(36.2\%) vs. 5명(21.7\%)으로 통계적으로 의미가 없었으며

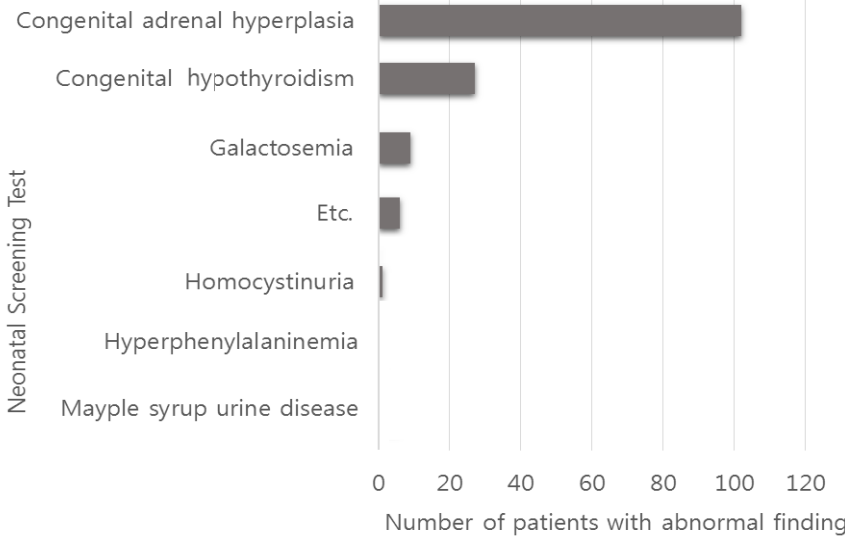

Fig. 1. Incidences of major metabolic diseases at 1st neonatal screening test. Etc. includes hyperglycinemia, propionic academia, tyrosinemia.

Table 2. Demographic Characteristics at 1st Exam according to Neonatal Screening Test Results

\begin{tabular}{lccc}
\hline Demographic parameters & $\begin{array}{c}\text { False-positive group } \\
(\mathrm{n}=142)\end{array}$ & $\begin{array}{c}\text { Normal group } \\
(\mathrm{n}=23)\end{array}$ & $P$-value \\
\hline After birth (hours) & $44.49 \pm 6.95$ & $46.22 \pm 8.27$ & 0.762 \\
$\leq 24$ & $2(1.4)$ & $0(0.0)$ & \\
$>24$ to 48 & $98(69.0)$ & $15(65.2)$ & \\
$>48$ to 72 & $42(29.6)$ & $8(34.8)$ & \\
Body weight $(\mathrm{kg})$ & $2.61 \pm 0.49$ & $1.93 \pm 0.25$ & 0.000 \\
Feeding volume $(\mathrm{mL} / \mathrm{kg})$ & $105.65 \pm 34.18$ & $89.40 \pm 39.69$ & 0.045 \\
$\geq 120$ & $51(35.9)$ & $3(13.0)$ & \\
100 to $<120$ & $40(28.2)$ & $6(26.1)$ & \\
80 to $<100$ & $23(16.2)$ & $4(17.4)$ & \\
$<80$ & $28(19.7)$ & $10(43.5)$ & \\
Total parenteral nutrition & & & \\
\hline Amino acid & $13(9.2)$ & $8(34.8)$ & 0.001 \\
\hline Lipid & $5(3.5)$ & $7(30.4)$ & 0.000 \\
Antibiotics & $49(34.5)$ & $5(21.7)$ & 0.226 \\
\hline
\end{tabular}

Values are presented as mean \pm standard deviation or number (\%).

$(P=0.226)$, 스테로이드를 투여한 환자는 위양성군과 대조군을 포함하여 단 한 명이어서 통계 과정을 생략하였다(Table 2).

위양성군과 대조군의 단순 비교에서 의미 있는 차이를 나타 낸 인자들을 정리하여 NST 결과에 영향을 미치는 정도를 파악 하고자 하였다. 출생시 성별, 출생 체중, 분만 방식 등의 인자들 과 초회 NST를 시행하는 시점에서 체중, 수유량, 총경정맥영양 종류 및 항생제 투여 등에 대한 이분형 로지스틱 회귀분석을 시 행하였다. 이 중 통계학적으로 유의미한 결과로는 여성일 경우 $(P=0.017)$ 와 출생 체중이 클수록 $(P=0.000)$ 위양성 결과가 나올 위험성이 컸다(Table 3). 
Table 3. Analysis of Major Parameters Affecting to Neonatal Screening Test Results

\begin{tabular}{lcccc}
\hline Demographic parameters & False-positive group $(\mathrm{n}=142)$ & Normal group $(\mathrm{n}=23)$ & $P$-value & OR of abnormal findings $(95 \% \mathrm{Cl})$ \\
\hline Male sex & $93(65.5)$ & $9(39.1)$ & 0.017 & $4.902(1.335-17.998)$ \\
Vaginal delivery & $68(47.9)$ & $5(21.7)$ & 0.636 & $0.636(0.168-2.405)$ \\
Birth weight $(\mathrm{kg})$ & $2.65 \pm 0.49$ & $1.95 \pm 0.25$ & 0.000 & $1.005(1.002-1.007)$ \\
Feeding volume $(\mathrm{mL} / \mathrm{kg})$ & $105.65 \pm 34.18$ & $89.40 \pm 39.69$ & 0.498 & $0.994(0.977-1.011)$ \\
TPN & $13(9.2)$ & $8(34.8)$ & 0.507 & $2.742(0.139-53.997)$ \\
Amino acid & $13(9.2)$ & $8(34.8)$ & 0.507 & $2.742(0.139-53.997)$ \\
Lipid & $5(3.5)$ & $7(30.4)$ & 0.505 & $0.636(0.168-2.405)$ \\
Antibiotics & $49(34.5)$ & $5(21.7)$ & 0.180 & $2.659(0.636-11.110)$ \\
\hline
\end{tabular}

Values are presented as mean \pm standard deviation or number (\%) unless otherwise indicated.

Abbreviations: $\mathrm{OR}$, odds ratio; $\mathrm{Cl}$, confidence interval; $T P N$, total parenteral nutrition.

\section{고찰}

전 세계적으로 해마다 1 천만 명 이상의 신생아가 선천성 대사 이상 및 유전질환에 대한 선별검사를 받고 있다. ${ }^{8}$ 일반적으로 처 음 NST 결과가 양성이거나 유효하지 않을 경우 재검사를 실시 해야 하고 재검에서도 양성이 나올 경우에는 정밀검사를 포함 한 확진검사를 실시하게 된다. 초기 양성 결과는 의심되는 질환 에 대한 조기 식별 등의 장점이 있는 반면 신생아들이 침습적인 재검을 감수해야 하는 불편함이 생기고 해당 검사 결과에 대한 자세한 설명이나 정보가 부족한 경우 보호자에게 심리적인 부담 이 되며, ${ }^{9}$ 위양성 결과에 따른 스트레스를 경험하기도 한다. ${ }^{10,11}$

이번 연구에서는 위양성이 보호자에게 끼치는 영향은 포함되 지 않았지만 이전 연구들에서 갑상선기능저하증 위양성 결과가 환자 부모에게 수면 이상, 우울 그리고 수유 문제들을 일으킬 수 있음을 보고한 연구가 있었고 ${ }^{12}$ 환자 본인에 게는 유아기 동안 산 모의 스트레스가 환자의 추후 스트레스 노출에 대한 시상하부뇌하수체-부신계(hypothalamic-pituitary-adrenal system)의 민감도를 증가시킬 수 있다는 보고도 있었다. ${ }^{13}$ 특히, 위양성 결 과를 받았던 환자들의 부모는 연이은 NST 음성 결과에도 환자 가 발달 지연이 올 수 있다는 두려움을 가지게 된다. ${ }^{14,15}$

선천성 대사이상질환을 확인하기 위한 NST가 1985년 국내 에 처음으로 도입된 후 ${ }^{1} 2006$ 년부터는 정부의 신생아 선별검사 사업이 총 6 개 질환으로 확대되어 무료로 시행되고 있다. ${ }^{16}$ 이 러한 대사이상질환들의 진단에 있어서도 1990년대 초부터 도 입된 탠덤매스 검사를 이용하여 기존의 방법으로 진단되지 않 았던 질환을 조기 발견할 수 있게 되어 매우 획기적인 검사로 인정받기도 하였다. ${ }^{17}$ 탠덤매스 검사는 선별검사 조건이 늘어나 도 소요되는 시간이나 가격 상승이 크지 않아 상대적으로 빠르 고 저렴하게 진단 범위를 넓힐 수 있어 ${ }^{18}$ 현재 대부분의 신생아 선별검사 기관에서 분석 기기로 탠덤매스 검사를 선택하고 있
다. 방법에 따라 60 가지 이상의 물질까지 분석 가능한 것으로 알 려져 있으며, ${ }^{8}$ 위양성률의 최소화로 질환이 있는 환자들 확인에 높은 민감도와 특이도를 보이는 것으로 되어 있다. ${ }^{19}$ 하지만 진 단 가능한 질환의 수가 많아짐에 따라 불가피하게 위양성률은 증가하게 되고, 앞서 언급하였던 것처럼 탠덤매스 검사의 위양 성률이 $0.33 \%$ 라고 볼 때 ${ }^{4}$ 현재 전국적으로 시행되고 있는 탠덤 매스 검사의 수를 고려하면 상당수의 신생아가 질병이 있다고 잘못 분류될 수 있다. 따라서 검사 방법 자체적으로 질환 여부 의 기준점을 재설정하는 것이 위양성률을 낮추기 위하여 필요 하다는 연구도 있었고, ${ }^{20}$ 이소길초산혈증(isovaleric acidaemia, IVA)의 표시자로 사용된 C5라는 표지자의 경우 검사시 2-methylbutyrylglycinuria 및 IVA의 기타 변이에서도 상승되고, ${ }^{21,22}$ 피발산(pivalic acid)을 포함하는 항생제 사용 시에도 상승되어 가양성 결과를 보일 수 있다는 연구도 있었다. ${ }^{23}$ 이번 연구에서 는 첫 번째 NST 검사 시점에서 위양성군과 대조군 사이에 체중 과 수유량, 총경정맥영양의 유무가 통계적으로 유의미한 차이 가 있었다. 이러한 차이는 위양성군의 평균 체중이 더 크게 분포 하면서 생기는 것으로 보이며 임상적인 의미를 부여하긴 힘들 어 보인다. 이분형 로지스틱 회귀분석을 하였을 때는 남아일수 록, 출생 체중이 클수록 위양성 결과의 위험성이 큰 것으로 나왔 다. 하지만 대조군의 크기가 위양성군과 차이가 많이 나고 NST 결과에 영향을 미칠 수 있는 주요한 인자인 출생 체중과 출생 주 수의 분포가 두 군 간에 상이하였기 때문에 이로 인한 선택 오차 (selection bias)의 가능성도 배제할 수 없었다. 또한 출생 체중 의 차이에 의한 odds ratio는 1.005 로 임상적으로 의미 있는 수 치로 보기 어려웠기 때문에 이에 대해서는 좀 더 대규모의 선택 오차를 줄인 연구가 더 필요할 것으로 보인다.

일반적으로 NST는 출생 후 3-7일에 시행되는 것으로 되어 있다. 너무 일찍 채혈을 하는 것은 혈중에 증가되어야 할 대사 물질들이 정상 범위에 있을 수 있고, 혈중 갑상선 자극 호르몬 
(TSH)이 출생 직후 높은 수치를 나타낼 수 있기 때문이다. ${ }^{2}$ 국민 의료보험 적용 후 정상 질식분만으로 출생한 신생아는 출생 후 신생아실에서 2-3일, 제왕절개로 태어난 신생아는 약 5일 정도 머무를 수 있다. 이에 따라 정상 질식분만으로 출생한 신생아의 경우나 조기에 산후조리원으로 산모 및 신생아가 이동하는 경 우 출생 후 72 시간을 채우지 못하고 NST가 시행되는 경우가 발 생할 수 있다. 이번 연구에서는 출생 후 24시간 간격으로 탠덤 매스 검사 시기를 구분해본 결과 임상적으로 유의미하게 위양 성 여부에 영향을 주는 주요 인자를 확인할 수 없었고, 이는 적 어도 72 시간 이후에 초회 검사를 진행해야 한다는 것을 재확인 하는 계기가 되었다.

이 연구의 한계점은 단일기관의 데이터를 이용하였고, 특히 일부 본원으로 전원되어 온 환자의 Apgar 점수를 포함한 출생 정보를 지역 분만 전문병원의 정보에 의존하였다는 것이다. 더 불어, NST에 영향을 주는 산모의 갑상선질환 여부를 제외한 기 타 산과적 문제를 정보 수집에서 제외하였다는 것이다. 수유 종 류에 있어서도 분유 및 모유를 구분하지 못하였고, 항생제 두 가 지를 개별적으로 나누지 못하였다. 초회 NST 검사 이상으로 선 천성 부신과형성증의 빈도가 제일 높았던 이유는 검사 의뢰기 관의 진단기준에 영향을 받았을 수 있을 것이다.

본 논문은 우연한 경우나 부득이한 상황으로 인하여 출생 후 만 72시간이 경과되지 않고 탠덤매스 검사를 진행할 경우 위양 성 결과에 영향을 줄 수 있는 인자들을 파악하여 NST 결과 해석 및 재검에 따르는 불편함을 최소화하고자 하였다. 위양성 결과 와 직접적인 연관이 있는 주요 인자를 확인하지 못하였지만 추 후 동일한 증례들을 모아 연구한다면 환자나 부모뿐만 아니라 의료진들에게 도움이 될 것으로 사료된다. 더불어 출생 후 입원 기간이 짧거나 주산기 정보가 충분하지 못한 경우 초회 NST 검 사를 외래 추적관찰 시점에서 시행하고 성별, 재태 연령 및 출생 체중과 함께 기타 약제 투약 여부를 포함한 자세한 정보를 확보 하여 NST 재검을 줄일 수 있도록 노력해야 하겠다.

\section{Acknowledgements}

This research was supported by Wonkwang University in 2018.

\section{References}

1) Lee $\mathrm{DH}$. Neonatal screening for inborn errors of metabolism. J Korean Pediatr Soc 1987;30:9-16.
2) Lee $\mathrm{DH}$. Newborn screening of inherited metabolic disease in Korea. Korean J pediatr 2006:49:1125-39.

3) Gurian EA, Kinnamon DD, Henry JJ, Waisbren SE. Expanded newborn screening for biochemical disorders: the effect of a false-positive result. Pediatrics 2006;117:1915-21.

4) Schulze A, Lindner M, Kohlmüller D, Olgemöller K, Mayatepek E, Hoffmann GF. Expanded newborn screening for inborn errors of metabolism by electrospray ionization-tandem mass spectrometry: results, out come, and implications. Pediatrics 2003;111(6 Pt 1):1399-406.

5) Song JY, Son DW, Kim BI, Yang SW, Choi JH, Yoon CK, et al. Re-evaluation of TSH screening test in neonates. J Korean Pediatr Soc 1993;36:1502-6.

6) Lee JM, Choi TY, Lee DW, Lee DH. Recheck rate, recall rate and reference range of the neonatal screening test for congenital hypothyroidism. J Clin Pathol Qual Control 2001;23:215-20.

7) Clinical and Laboratory Standards Institute. Newborn screening for preterm, low birth weight, and sick newborns; approved guideline. CLS document NBS03-A. Wayne (PA): Clinical and Laboratory Standards In stitute; 2009

8) Clinical and Laboratory Standards Institute. Newborn screening by tandem mass spectrometry; approved guideline. CLSI document NBS04-A. Wayne (PA): Clinical and Laboratory Standards Institute; 2010.

9) Fant KE, Clark SJ, Kemper AR. Completeness and complexity of information available to parents from newborn-screening programs. Pediatrics 2005;115:1268-72

10) Green JM, Hewison J, Bekker HL, Bryant LD, Cuckle HS. Psychosocial aspects of genetic screening of pregnant women and newborns: a systematic review. Health Technol Assess 2004;8:iii, ix-x, 1-109.

11) Kwon $C$, Farrell PM. The magnitude and challenge of false-positive newborn screening test results. Arch Pediatr Adolesc Med 2000;154:714-8.

12) Bodegård G, Fyrö K, Larsson A. Psychological reactions in 102 families with a newborn who has a falsely positive screening test for congenita hypothyroidism. Acta Paediatr Scand Suppl 1983;304:1-21.

13) Essex MJ, Klein MH, Cho E, Kalin NH. Maternal stress beginning in infancy may sensitize children to later stress exposure: effects on cortisol and behavior. Biol Psychiatry 2002;52:776-84.

14) Green M. Vulnerable child syndrome and its variants. Pediatr Rev 1986 8:75-80.

15) Leslie LK, Boyce WT. Consultation with the specialist. The vulnerable child. Pediatr Rev 1996;17:323-6.

16) Choi TY, Kim JW, Min WK, Lee DH. Analysis of blood sample records for neonatal screening test and external quality assessment for inborn errors of metabolism in Korea. J Korean Soc Matern Child Health 2003;7:7-17.

17) Lee $\mathrm{DH}$. The prevalence of pediatric endocrine and metabolic diseases in Korea. Korean J Pediatr 2008;51:559-63.

18) American College of Medical Genetics/American Society of Human Genetics Test and Technology Transfer Committee Working Group. Tandem mass spectrometry in newborn screening. American College of Medical Genetics/American Society of Human Genetics Test and Technology Transfer Committee Working Group. Genet Med 2000;2:2679.

19) Matern D, Tortorelli S, Oglesbee D, Gavrilov D, Rinaldo P. Reduction of 
the false-positive rate in newborn screening by implementation of MS/ MS-based second-tier tests: the Mayo Clinic experience (2004-2007). J Inherit Metab Dis 2007;30:585-92.

20) Shim KS, Hwang JS, Lim JS, Kim SY, Shin CH, Yang SW, et al. Re-evaluation of neonatal screening tests for inborn errors of metabolism with dried filter paper blood spots. J Korean Pediatr Soc 1999;42:1639-44.

21) Ensenauer R, Vockley J, Willard JM, Huey JC, Sass JO, Edland SD, et al. A common mutation is associated with a mild, potentially asymptomatic phenotype in patients with isovaleric acidemia diagnosed by newborn screening. Am J Hum Genet 2004;75:1136-42.

22) Matern $D$, He M, Berry SA, Rinaldo P, Whitley CB, Madsen PP, et al. Prospective diagnosis of 2-methylbutyryl-CoA dehydrogenase deficiency in the Hmong population by newborn screening using tandem mass spectrometry. Pediatrics 2003;112(1 Pt 1):74-8.

23) Abdenur JE, Chamoles NA, Guinle AE, Schenone AB, Fuertes AN. Diagnosis of isovaleric acidaemia by tandem mass spectrometry: false positive result due to pivaloylcarnitine in a newborn screening programme. J Inherit Metab Dis 1998;21:624-30. 